\title{
A Review on the Potency of Melaleuca leucadendron Leaves Solid Waste in Wood Preservation and Its In Silico Prediction upon Biological Activities
}

\author{
Christine Patramurti $\left(\mathbb{D},{ }^{1}\right.$ Radjali Amin $\left(\mathbb{D},{ }^{2}\right.$ Christofori M. R. R. Nastiti $\left(\mathbb{D},{ }^{1}\right.$ \\ and Maywan Hariono iD ${ }^{1}$ \\ ${ }^{1}$ Faculty of Pharmacy, Sanata Dharma University, Sleman, Daerah Istimewa, Yogyakarta 55282, Indonesia \\ ${ }^{2}$ Post-Graduate School, Yogyakarta Institute of Technology, Bantul, Daerah Istimewa, Yogyakarta 55198, Indonesia \\ Correspondence should be addressed to Maywan Hariono; mhariono@usd.ac.id
}

Received 29 September 2020; Revised 29 October 2020; Accepted 3 November 2020; Published 17 November 2020

Academic Editor: Ahmad A. Omar

Copyright (c) 2020 Christine Patramurti et al. This is an open access article distributed under the Creative Commons Attribution License, which permits unrestricted use, distribution, and reproduction in any medium, provided the original work is properly cited.

\begin{abstract}
The essential oils from cajuput leaves (Melaleuca leucadendron) have been well-known and applied, especially in healthcare management. However, the utilization of the leaves solid waste has not been explored and reported in detail. In this review, we elaborate on the cajuput leaves starting from the plant description and leaf morphology, chemical composition, biological activities, wood decomposing organism, and an in silico prediction upon its molecular mechanism. Based on the in silico prediction, compounds such as guaiol, lupene, and 1, 8-cineole have the potential to be antifungal and insecticide that associates with the cajuput potency as a wood preservative agent.
\end{abstract}

\section{Introduction}

The leaves and small branches distillation process of cajuput (Melaleuca leucadendron (L.) L.) produces essential oils with eucalyptol (cineole) as the main chemical substance (50-65\%) [1]. Eucalyptol (1, 3, 3-trimethyl-2-oxabicyclo [2.2.2] octane) is classified as the oxygenized monoterpene hydrocarbon group. This compound plays an important role in its antibacterial activity against Gram-positive and Gramnegative bacteria. The biological activities were also reported against fungus and insects which could be due to that one of the major eucalyptol compounds borne a chemical structure as 1, 8-cineole (Figure 1) [1].

Besides the essential oils, the distillation process of cajuput produces solid residue (waste), i.e., the cajuput leaves mixed with small and big branches. The leaves solid waste still contains the essential oil which composes chemicals similar to its fresh leaves when they were distilled. In Maluku (Indonesia), the waste was produced in approximately 51 million tons per year up to 2013 [2], whereas in West Java, the waste production was up to 8.3 million tons per year [3]. It is only about $14 \%$ of waste was estimated to be directly utilized by the cajuput distillation factory [4].

The research reported that solid cajuput waste can be used as activated charcoal [5]. The waste can be further processed as the biopellet and briquette charcoals [6]. The calorie value of cajuput briquette charcoal is much higher than the common briquette charcoals [2] that can reach up to 1.5 times magnitude $[7,8]$. This solid waste also contains volatile gases with a quantity of up to $47-68 \%[5,7]$. This waste was also utilized as fuel such as in a steam boiler [9] and as a food substitute for cow cattle on the farm [10]. A study by Rahmawati et al. reported that cajuput waste can be processed as an organic soil fertilizer [4]; however, the process of decomposition was slow triggering several studies to investigate the environmental factors accelerating this waste decomposition process [11]. Interestingly, no study has been carried out to investigate the chemical substances in cajuput solid waste which might slow down the decomposition process. 


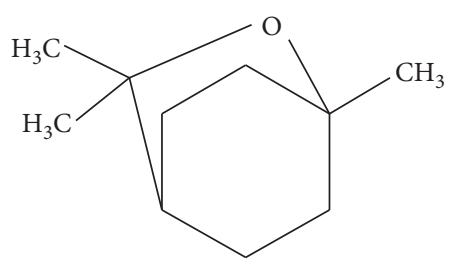

Figure 1: The chemical structure of 1, 8-cineole.

The 1,8-cineole which is one of the main components of eucalyptol [1] is predicted as the chemical which inhibits the decomposition due to its activities as an antibacterial, antifungal, and insecticide agent. To date, no study identifies the concentration of 1,8-cineole in the cajuput leaves solid waste and the probability of other compounds supporting the role in the decomposition inhibition. It is estimated that if these chemicals can be well isolated, they may be further utilized in the wooden furniture preservation, thereby increasing the economic values of the solid cajuput waste. This review article focuses on the progress studying the chemical constituent identification and the biological activities of cajuput leaves. Subsequently, the in silico prediction on how the chemicals in cajuput leaves solid waste interact with the protein expressed by wood decomposing microorganisms is also reviewed.

\section{Plants Description and Leaf Morphology}

The genus of Melaleuca (Myrtaceae family) covers at least 230 species in the world, mostly found in Tasmania (Australia), Indonesia, Papua New Guinea, Tropical America, and South Asia $[12,13]$. The main genera utilized for the production of commercial essential oils and aromatherapy are Melaleuca alternifolia (Maiden and Betche) Cheel (tea tree oil), Melaleuca cajuputi Powell (cajuput oil), and Melaleuca quinquenervia (Cav.) S. T. Blake (niaouli oil). Other well-known genera are Melaleuca leucadendron, Melaleuca viridiflora, Melaleuca acacioides, Melaleuca alsophila, Melaleuca bracteata, and Melaleuca argentea $[14,15]$. The trees of Melaleuca leucadendron are approximately $40 \mathrm{~m}$ high, which is grown in northern Australia, the south coast of New-Guinea, and the east coasts of Indonesia [12]. The morphology of Melaleuca leucadendron leaves is a blade narrowly ovate, very narrowly ovate, rarely narrowly elliptic, or very narrowly elliptic (often falcate to subfalcate). The leaves are 3.5-16 times longer compared to the width; petals are with elliptic oil glands (occasionally long elliptic glands form an apparently linear gland) [16]. The tree of cajuput and its leaves are presented in Figure 2. A number of protocols have been applied to standardize the components of the leaves and the extract including phytochemical screening, thin layer chromatography profile, organoleptic evaluation, histological and microscopic techniques of leaves, powder microscopic, physicochemical parameters, quantitative microscopy, and evaluation of volatile oil [17-23].

\section{Chemical Compositions}

Most of the chemical composition of cajuput was found from its leaves. The (E, S)-nerolidol and related alcohols such as farnesol and geraniol were found from the leaves of Melaleuca leucadendron which was used in feeding deterrent of the gypsy moth larvae [24]. The high content of two phenylpropanoid chemotypes was furthered isolated from the Melaleuca leaves, which were methyl eugenol (99\%) and methyl isoeugenol ( $88 \%$; both in $Z$ and $E$ configuration). On the other hand, small amounts of trans- $\beta$-ocimene and linalool were also detected [25]. The chemical structure of eugenol, isoeugenol, trans- $\beta$-ocimene, and linalool is illustrated in Figures 3(a)-3(d), respectively.

By distillation, the fresh leaves of cajuput were producing essential oils containing $a$-pinene, $\beta$-pinene, $\beta$-myrcene, limonene, $\gamma$-terpinene, 1,8 -cineole, $p$-cymene, terpinolene, benzaldehyde, linalool, trans-pinene hydrate, terpin-4-ol, $\gamma$-terpineol, $\alpha$-terpineol, 1 -tetradecene, ledol, valencene, eugenol, $\alpha$-eudesmol, and $\beta$-eudesmol as the main constituents (64\%) [15]. The similar distillation process was carried out to hydrodistill essential oil from cajuput leaves observing the other major constituents such as $\beta$-eudesmol (15.8\%), $\alpha$-eudesmol (11.3\%), viridiflorol (8.8\%), and guaiol (9.0\%) (Figures 3(e)-3(h), respectively) [26].

A study by Yoshida et al. on the chemical identification of cajuput dried fruits indicated a new hydrolyzable tannin and other polyphenols as the secondary metabolite being deposited. They were 1, 2-di-O-galloyl-3-O-digalloyl-4, 6-O(S)-hexahydroxydiphenoyl-3-I $\beta$-glucose (Figure 4(a)) and nine known hydrolyzable tannins. Commonly known stilbene glycoside and triterpene were also identified [27].

A comprehensive study was successfully performed to identify further triterpene from the leaves and heartwood of cajuput. A novel lupene-type nortriterpene (28-norlup-20(29)ene- $3 \beta, 17 \beta$-diol) as well as 13 other known compounds were characterized. The other 13 compounds were (2E, 6E)-farnesol, phytol, squalene, alloaromadendrene, ledene, palustrol, viridiflorol, ledol, betulinaldehyde, betulinic acid, $3 \beta$-acetyl-lup20(29)-en-28-oic acid, 3-oxolup-20(29)-en-28-oic acid, and platanic acid [28]. Further novel triterpenes were characterized, i.e., $3 \beta$-cis-coumaroyloxy- $2 \alpha$-hydroxyursa- 12 , 20(30)-dien-28oic acid, and cis- and trans- $3 \beta$-caffeoyloxy- $2 \alpha$-hydroxyurs-12en-28-oic acids from the leaves as well [29]. Research also successfully identified three new triterpenes from the heartwood of cajuput [30]. They are 23-trans-p-coumaroyloxy- $2 \alpha$, $3 \beta$-dihydroxyolean-12-en-28-oic acid, $3 \beta$-trans-caffeoyloxy$2 \alpha$,23-dihydroxyolean-12-en-28-oic acid, and its isomer $3 \mathrm{p}$ cis-caffeoyloxy-2 $\alpha, 23$-dihydroxyolean-12-en-28-oic acid [31]. The general structure of lupene is shown in Figure 4(b).

Having isolated from the heartwood, four new triterpenes were characterized including eupha-7, 24-diene- $3 \alpha$, $22 \alpha$-diol, 20-taraxastene-3R, 28-diol, 3R-hydroxy-13(18)oleanene-27, 28-dioic acid, and 3R, 27-dihydroxy-28, 20 $\alpha$ taraxastanolide. Besides, Lee also identified four novel $\beta$-triketone flavanones from the leaves. The compounds were then named as leucadenone A to leucadenone D [32]. 


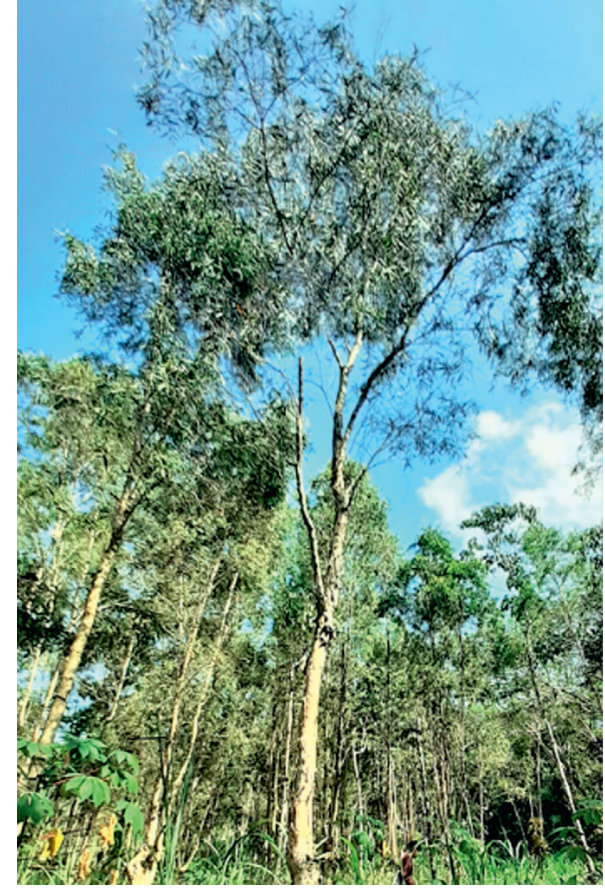

(a)

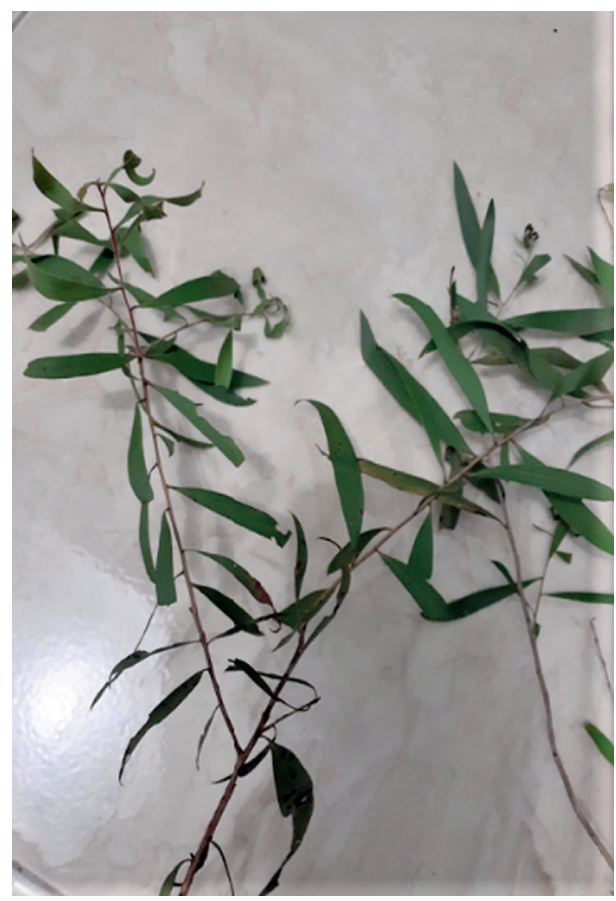

(b)

Figure 2: The habitus of (a) tree of cajuput and (b) its leaves. The photos were taken in Sendang Mole, Playen, Gunung Kidul, Daerah Istimewa Yogyakarta.<smiles>C=CCc1ccc(O)c(OC)c1</smiles>

(a)

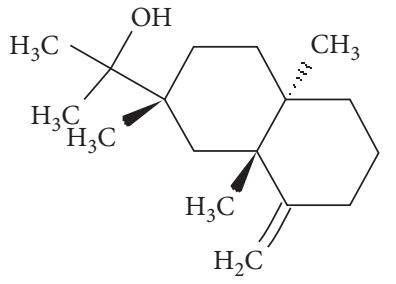

(e)<smiles>C/C=C/c1ccc(O)c(OC)c1</smiles>

(b)<smiles>CC1=CCC[C@]2(C)CC[C@](C)(C(C)(C)O)C[C@]12C</smiles>

(f)<smiles>C=C/C(C)=C/CC=C(C)C</smiles>

(c)<smiles>C[C@H]1CC[C@@H]2[C@H]([C@H]3[C@H]1CC[C@H]3C)C2(C)C</smiles>

(g)<smiles>C=CC(C)(O)CCC=C(C)C</smiles>

(d)

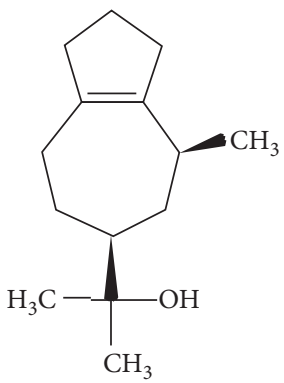

(h)

FIGUre 3: The chemical structure of (a) eugenol, (b) isoeugenol, (c) trans- $\beta$-ocimene, (d) linalool (e) $\beta$-eudesmol, (f) $\alpha$-eudesmol, (g) viridiflorol, and (h) guaiol which are benefit for the antibacterial effect and are the components of hydrodistilled essential oil from cajuput leaves. 
<smiles>O=C(OCC1OC2COC(=O)c3cc(O)c(O)c(O)c3-c3c(cc(O)c(O)c3O)C(=O)OC2C(O)C1OC(=O)c1cc(O)c(O)c(O)c1)c1cc(O)cc(O)c1</smiles>

(a)<smiles></smiles>

(b)

FIgure 4: The chemical structure of (a) 1, 2-di-O-galloyl-3-O-digalloyl-4, 6-O-(S)-hexahydroxydiphenoyl-3-I $\beta$-glucose, the chemical composition of cajuput fruits, and (b) the general structure of lupene which are the chemical composition of the leaves.

TABLE 1: Identification and quantification of the compounds in cajuput (Melaleuca leucadendron) (reported in 2011-2020).

\begin{tabular}{|c|c|c|c|c|}
\hline No. & Compounds & Part & $\%$ or $\mathrm{mg}$ & References \\
\hline 1 & $\alpha$-Pinene & Leaves & $0.22-0.68$ & [33] \\
\hline 2 & $\alpha$-Thujene & Leaves & $1.29-4.16$ & [33] \\
\hline 3 & $\beta$-Pinene & Leaves & $0.79-2.90$ & {$[33]$} \\
\hline 4 & $\beta$-Myrcene & Leaves & $0.31-0.95$ & {$[33]$} \\
\hline 5 & Carene & Leaves & $0.29-1.18$ & {$[33]$} \\
\hline 6 & $D(+)$-limonene & Leaves & $4.45-8.85$ & {$[33]$} \\
\hline 7 & $\gamma$-Terpinene & Leaves & $1.82-6.72$ & {$[33]$} \\
\hline 8 & Terpinolene & Leaves & $0.67-3.62$ & {$[33]$} \\
\hline 9 & 1,8-Cineole & Leaves & $44-60$ & {$[33]$} \\
\hline 10 & Linalool & Leaves & $0.00-0.42$ & [33] \\
\hline 11 & Terpinene-4-ol & Leaves & $0.63-0.97$ & [33] \\
\hline 12 & Ocimenol & Leaves & $0.09-0.20$ & {$[33]$} \\
\hline 13 & $\alpha$-Terpineol & Leaves & $5.93-12.45$ & {$[33]$} \\
\hline 14 & $\gamma$-Terpineol & Leaves & $0.36-2.06$ & {$[33]$} \\
\hline 15 & Cedrene & Leaves & $0.00-0.61$ & [33] \\
\hline 16 & $\beta$-Caryophyllene & Leaves & $3.78-7.64$ & {$[33]$} \\
\hline 17 & Humulene & Leaves & $0.53-0.88$ & {$[33]$} \\
\hline 18 & $\beta$-Eudesmene & Leaves & $0.98-3.51$ & {$[33]$} \\
\hline 19 & Patchoulene & Leaves & $0.82-4.37$ & [33] \\
\hline 20 & Germacrene D & Leaves & $0.17-0.60$ & {$[33]$} \\
\hline 21 & Aromadendren & Leaves & $0.00-0.27$ & {$[33]$} \\
\hline 22 & Globulol & Leaves & $2.70-3.60$ & {$[33]$} \\
\hline 23 & Viridiflorol & Leaves & $0.00-0.36$ & {$[33]$} \\
\hline 24 & Eugenol & Leaves & $2.68-4.85$ & {$[33]$} \\
\hline 25 & 2-Pentanone & Leaves & $5.0 \mathrm{mg}$ & {$[33]$} \\
\hline 26 & Melachromone & Leaves & $2.4 \mathrm{mg}$ & {$[34]$} \\
\hline 27 & Parietin & Leaves & $33.2 \mathrm{mg}$ & {$[34]$} \\
\hline 28 & 5-Hydroxy-7-methoxy-2, 6, 8-trimethylchromone & Leaves & $11.7 \mathrm{mg}$ & {$[34]$} \\
\hline 29 & Eugenitin & Leaves & $10.2 \mathrm{mg}$ & {$[34]$} \\
\hline 30 & 2, 5-Dihydroxy-7-methoxy-2, 6-dimethylchromanone & Leaves & & [34] \\
\hline 31 & 2, 5-Dihydroxy-7-methoxy-2, 8-dimethylchromanone & Leaves & $2.4 \mathrm{mg}$ & {$[34]$} \\
\hline 32 & Noreugenin & Leaves & $8.3 \mathrm{mg}$ & {$[34]$} \\
\hline 33 & 5, 7-Dihydroxy-2, 6, 8-trimethylchromone & Leaves & $4.8 \mathrm{mg}$ & {$[34]$} \\
\hline 34 & Methyl 2-acetyl-3, 5-dihydroxyphenylacetate & Leaves & $14.4 \mathrm{mg}$ & {$[34]$} \\
\hline 35 & Quercitrin & Leaves & $3.0 \mathrm{mg}$ & {$[34]$} \\
\hline 36 & $\beta$-Sitosterol & Leaves & $8.0 \mathrm{mg}$ & {$[34]$} \\
\hline 37 & 5-Hydroxy-7, 40-dimethoxy-6, 8-dimethylflavone & Leaves & $12 \mathrm{mg}$ & {$[34]$} \\
\hline 38 & $3,3^{\prime}, 4$-Tri-O-methylellagic acid & Leaves & 0.04 & {$[34]$} \\
\hline 39 & Camphene & Leaves & 0.14 & {$[35]$} \\
\hline
\end{tabular}


TABle 1: Continued.

\begin{tabular}{|c|c|c|c|c|}
\hline No. & Compounds & Part & $\%$ or $\mathrm{mg}$ & References \\
\hline 40 & $L$-limonene & Leaves & 0.04 & [35] \\
\hline 41 & Rose oxide & Leaves & 0.13 & [35] \\
\hline 42 & Isopulegol & Leaves & 0.24 & {$[35]$} \\
\hline 43 & Neral & Leaves & 0.13 & {$[35]$} \\
\hline 44 & Geraniol & Leaves & 0.31 & {$[35]$} \\
\hline 45 & Geranial & Leaves & 0.14 & {$[35]$} \\
\hline 46 & A-terpenyl acetate & Leaves & 0.23 & {$[35]$} \\
\hline 47 & $\Delta$-Elemene & Leaves & 0.37 & {$[35]$} \\
\hline 48 & $\alpha$-Ylangene & Leaves & 0.36 & {$[35]$} \\
\hline 49 & $\alpha$-Cubebene & Leaves & 1.01 & [35] \\
\hline 50 & $\beta$-Elemene & Leaves & 0.16 & {$[35]$} \\
\hline 51 & $\alpha$-Gurjunene & Leaves & 0.55 & [35] \\
\hline 52 & Linalyl acetate & Twigs & 0.11 & {$[36,37]$} \\
\hline 53 & Bornyl acetate & Leaves & 0.60 & {$[36,37]$} \\
\hline 54 & $\beta$-Bourbonene & Flowers & 2.67 & {$[36,37]$} \\
\hline 54 & $(E)$ - $\beta$-Farnesene & Flowers & 0.10 & {$[36,37]$} \\
\hline 55 & (Z)-Nerolidol & Twigs & 90.85 & {$[36,37]$} \\
\hline 56 & $(E)$-Nerolidol & Leaves & 0.20 & {$[36,37]$} \\
\hline 57 & Epi- $\alpha$-cadinol & Leaves & 0.79 & {$[36,37]$} \\
\hline 58 & $\beta$-Bisabolol & Flowers & 0.25 & {$[36,37]$} \\
\hline 59 & (Z)-Nerolidyl acetate & Twigs & 0.25 & {$[36,37]$} \\
\hline 60 & Palustrol & Leaves & 1.86 & {$[36,37]$} \\
\hline 61 & Ledol & Leaves & 0.87 & {$[36,37]$} \\
\hline 62 & Bulnesol & Leaves & 0.21 & {$[36,37]$} \\
\hline 63 & Alloaromadendrene & Leaves & NR & {$[36,37]$} \\
\hline 64 & Melaleucadines A & Branches and leaves & NR & [38] \\
\hline 65 & Melaleucadines B & Branches and leaves & 0.8 & [38] \\
\hline 66 & 3-Allyl-2-methoxyphenol & Leaves & 0.8 & {$[39]$} \\
\hline 67 & (E)-Methyl cinnamate & Leaves & 95.4 & [39] \\
\hline 68 & Eugenol methyl ether & Leaves & NR & {$[39]$} \\
\hline 69 & (E)-3, 7-Dimethylocta-2, 6-dienal & Leaves & NR & {$[40]$} \\
\hline 70 & $1,1,4,7$-Tetramethyl-1a, 2, 3, 4, 4a, 5, 6, 7b-octahydro- & Leaves & NR & {$[40]$} \\
\hline 71 & $1 \mathrm{H}$-cyclopropa $[\mathrm{e}]$ azulene & Fruits & NR & {$[41]$} \\
\hline 72 & (+)-Leumelaleucol A & Fruits & NR & {$[41]$} \\
\hline 73 & (-)-Leumelaleucol A & Fruits & NR & {$[41]$} \\
\hline 74 & Leumelaleucol B & Fruits & NR & {$[41]$} \\
\hline 75 & Leumelaleucol C & Fruits & NR & {$[41]$} \\
\hline 76 & Leumelaleucol D & Fruits & NR & {$[41]$} \\
\hline 77 & Leumelaleucol E & Fruits & NR & {$[41]$} \\
\hline 78 & Leumelaleucol F & Fruits & NR & {$[41]$} \\
\hline 79 & Leumelaleucol G & Fruits & NR & {$[41]$} \\
\hline 80 & Leumelaleucol H & Fruits & NR & {$[41]$} \\
\hline 81 & Leumelaleucol I & Fruits & NR & {$[41]$} \\
\hline 82 & Leumelaleucol J & Fruits & NR & {$[41]$} \\
\hline
\end{tabular}

NR, not reported.

The investigation of the chemical component in the cajuput has been highly developed in a decade. Novel and known compounds were reported enriching the database of compounds from cajuput (Table 1), which were potential to be developed as medicine, cosmetics, aromatherapy, and fiber technology.

\section{Biological Activities}

The preservative effect of cajuput leaves was introduced due to its chemical composition to eradicate microorganisms. Biological activities of cajuput against some microbes including bacteria, fungi, virus, and insects are summarized below.
4.1. Antibacterial. Cajuput oil, which was hydrodistilled from the leaves, was tested against the methicillin-resistant Staphylococcus aureus (MRSA) colony [42]. The minimum bactericidal concentration (MBC) and the minimum inhibition concentration (MIC) were found to be $0.2 \%$ and $0.4 \%$, respectively. This suggested that the leaves oil was able to inhibit the resistant bacteria growth in very low concentrations. This finding could be the potential to overcome bacterial resistance which has currently become an urgent public health issue. Furthermore, the antibacterial test against MRSA was also carried out on the ethanol extract of cajuput leaves. Maceration was used to extract the bactericidal constituents from the leaves, and the extract was 
tested onto the bacteria using a good well diffusion method. The results demonstrated that ethanol extract was able to inhibit the growth of bacteria. The concentrations of $50 \%$, $60 \%, 70 \%, 80 \%, 90 \%$, and $100 \%$ showed an inhibition zone of $17.2 \mathrm{~mm}, \quad 18.1 \mathrm{~mm}, \quad 19.1 \mathrm{~mm}, 19.4 \mathrm{~mm}, 19.7 \mathrm{~mm}$, and $20.1 \mathrm{~mm}$, respectively [43]. The ethanol extract of cajuput oil was also previously inhibiting Escherichia coli bacterial growth with an MIC of $64 \mu \mathrm{g} / \mathrm{mL}$ [44].

Cajuput essential oil from leaves demonstrated appreciable activity against Enterobacter aerogenes with inhibition zone 13.7-16.2 mm [39]. Enterobacter aerogenes is the Gram-negative bacteria of the Enterobacteriaceae family causing bacterial infection in the wound and the respiratory as well as the urinary tract [45].

4.2. Antifungal. The antifungal activity of the cajuput leaf essential oils had been determined against Fusarium oxysporum, Thanatephorus cucumeris, and Rhizopus oryzae [46]. The results showed that the oils were active against $F$. oxysporum with $\mathrm{IC}_{50} 0.01-0.11 \mathrm{mg} / \mathrm{mL}$ and against Thanatephorus cucumeris with $\mathrm{IC}_{50} 0.52-4.20 \mathrm{mg} /$ $\mathrm{mL}$, but less active against $R$. oryzae as it only showed $\mathrm{IC}_{50}$ of $1.35-7.61 \mathrm{mg} / \mathrm{mL}$. Fusarium oxysporum is a soilborne pathogen bacteria that cause vascular wilts in several plants [47]. Thanatephorus cucumeris which is classified as basidiomycetes also causes plant diseases to numerous agricultural and horticultural plants worldwide [48]. Rhizopus oryzae is a parasitic fungus that penetrates in the citrus fruit tissue through microwounds and bruises [49].

Along with the above studies, the antifungal assay of cajuput leaf oils was also determined against Fomitopsis palustris, Tinea versicolor, and Chaetomium globosum. According to Rini et al., the cajuput leaf oils demonstrated antifungal activities with $\mathrm{IC}_{50} \quad 0.12-3.16 \mathrm{mg} / \mathrm{mL}$, $0.01-0.06 \mathrm{mg} / \mathrm{mL}$, and $0,06-0.15 \mathrm{mg} / \mathrm{mL}$ for Fomitopsis palustris, Tinea versicolor, and Chaetomium globosum, respectively [50]. F. palustris enzymatically breaks down the cellulose of wood and leads to the plant disease namely brown rot [51], whereas Chaetomium globosum is an endophytic fungus assisting the cellulose decomposition of plant cells [52]. T. versicolor which is known as a turkey tail mushroom exhibits anticancer activities due to the polysaccharide constituents [53]. Candidiasis is a fungal infection which commonly occurs in female, particularly in the female reproductive organ. The cajuput leaf oils potentially eradicated the Candida albicans with MIC $62.5 \mu \mathrm{g} / \mathrm{mL}$ which is comparable to ketoconazole, the well-known synthetic drug used to treat candidiasis [54].

4.3. Antivirus. The potential antiviral activity of cajuput aqueous and methanol extracts were investigated against herpes simplex virus-1 (HSV-1) [55]. The aqueous extract demonstrated a $55.6 \%$ plaque reduction activity. Interestingly, at the same concentration $(100 \mu \mathrm{g} / \mathrm{mL})$, the methanol extract exhibited a $100 \%$ plaque reduction defining the antiviral effect of such a plant against HSV-1. This potentially reduced the mouse skin lesions and the mortality of the subject of the study for sure. A study by Farag et al. on HSV1 was also conducted to evaluate the antiviral activity of the fresh leaves oil of cajuput. This supported the previous finding that cajuput was able to inhibit HSV-1 which infected African green monkey kidney cells (Vero cell) with $92 \%$ of inhibition [15].

4.4. Repellent Activity. Cajuput leaf oil demonstrated repellent activities against Aedes (43.2\%), Anopheles (100\%), and Culex mosquitoes (100\%) during eight hours of mosquito exposure [56]. When the oil was tested into the larvae of Aedes, it showed the larvicidal activity up to $3.3 \%$ at a concentration of $50 \mathrm{ppm}$ [57]. A similar study was conducted by Noosidum et al. confirming the repellent activity of the oil against female Aedes aegypti mosquitoes. A high escape rate of the mosquitoes was observed for up to 24 hours [58].

Further insect repellent activities of cajuput leaf oils against the vector of dengue and filariasis were reported $[59,60]$. The oil was showing $97.5 \%$ repellency when it was exposed to Lasioderma serricorne, which was a serious pest of tobacco leaves cigarettes, cocoa beans, cereals, oilseeds, pulses, spices, and dried fruits [61]. Another study of the repellency effect of cajuput leaf oils against Sitotroga cerealella was also reported. The oil repelled up to $61 \%$ after the photo natural period of Sitotroga cerealella, a Lepidoptera insect which causes an unpleasant smell of grains [62]. Cajuput leaf oils were also reported to have repellent activities against Plutella xylostella, the most important pest in cabbage [63].

4.5. Wood Decomposing Organisms. Organic material decomposition is carried out by microbes or mesofauna. This process breaks down the materials into basic elements such as $\mathrm{N}, \mathrm{P}, \mathrm{K}, \mathrm{Mg}$, and $\mathrm{Ca}$, which are important for soil nutrients [64]. The microbes or mesofauna are often utilized as wood decomposers especially for the lignin and cellulose matters [65]. These decomposers are divided into primary and secondary decomposers.

The primary decomposer is a mesofauna such as Collembola and Acarina which converts large particles into micronized sizes [66]. A wood decomposition process is also generally related to macrowood decomposers, which could be insects and termites [67]. When the trees are logged down, the decomposers start to attack the wood, especially to that sapwood which is rich in cellulose and carbohydrate. The moist environment further supports the existence of the wood decomposers in the trees [68]. Hollowish trees including rubber (Hevea brasiliensis), palm oil (Elaeis sp.), walnuts (Canarium vulgare), and fire tree (Delonix regia) are commonly attacked by ground/subterranean termites (genus of Coptotermes) [69].

The wood decomposition process quickly occurs once the trees died or fallen down. This is because neither defense nor a tree recovery is leading to the direct contact between the dead trees with the ground rich of decomposers. This attack is also performed by the genus of Coptotermes due to the chemical substance such as eugenol which attracts the 
termites to come over the trees [70]. Moreover, a derivative of eugenol, i.e., methyl eugenol $\left(\mathrm{C}_{12} \mathrm{H}_{24} \mathrm{O}_{8}\right)$ has a function to stimulate the olfactory sensory organ in termites [71]. In conjunction with this, the termites have been successfully identified as a living wood attacker to cajuput which is the genus of Odontotermes [72]. Focusing on the cajuput tree, the Macrotermes gilvus termites attack is unavoidable even though the trees are still growing [73], especially to those of roots as well as the branches [74].

Muslich and Rulliaty examined the durability of the processed wood of cajuput from three types of decomposer's attack, i.e., dried ground termites (Cryptotermes cynocephalus Light), common ground termites (Coptotermes curvignathus Holmgren), and marine wood termites conclude that cajuput is resistant toward the attack of Coptotermes curvignathus but is vulnerable toward other decomposers [75]. This protective effect might be due to the chemical constituent such as cineole, melaleucin, and terpineol [76].

The secondary decomposers are mostly in the form of fungi, including Trichoderma reesei, Trichoderma harzianum, Trichoderma koningii, Phanerochaete chrysosporium, Cellulomonas, Pseudomonas, Thermospora, Aspergillus Niger, Aspergillus terreus, Penicillium, and Streptomyces [77]. According to Eriksson et al., fungus is the most active decomposer which immediately converts organic materials into simpler organic elements [78]. Suprapti and Djarwanto successfully identified some fungi attacked to cajuput including Pycnoporus sanguineus, Polyporus, Trametes, Schizophyllum commune, Chaetomium globosum, Marasmius, and Dacryopinax spathularia. Pycnoporus sanguineus is known to be the strongest attacker among them, followed by the genus of Polyporus [79]. Fortunately, although being attacked by fungi, the chemical composition especially the essential oils can block it. Sri et al. confirmed that the cellulose content of cajuput wood was still relatively high compared to other wood samples such as pine (Pinus merkusii), rubber (Hevea brasiliensis), and sengon (Paraserianthes falcataria) after inoculated by the fungus as the decomposer [80].

The wood decomposition is accelerated by the enzymatic process which is expressed by microorganism cells [81]. This enzymatic process includes hydrolysis as well as oxidation to degrade the cellulose [82] and to depolymerize the lignin [83]. This degradation and depolymerization reduce the particle size of cellulose and lignin while dissolving them into water. As in common enzyme, the catalytic process is limited by the substrate suitability, humidity, and temperature. On the one hand, a cellulose enzyme actively decomposes cellulose into its soluble form yielding cellodextrin $(6 \mathrm{C})$, cellobiose (4C), and glucose (2C) [84]. On the other hand, the activity of laccase and peroxidase degrade the lignin into a red color product containing quinone as an oxidized product of guaiacol [85]. The cellulose enzyme is expressed by Chaetomium sp. [86], whereas the laccase and peroxidase enzyme are produced by the genus of Trametes [87].

4.6. In silico Prediction of the Antidecomposing Effect of Cajuput. In silico method can be potentially used to study the activity of chemical substances in cajuput oil regarding the inhibition effect to the decomposing microbial enzymes. Interaction between the $3 \mathrm{D}$ structure of the enzyme and the molecule structure of the chemical of interest can be well investigated by using computational methods $[88,89]$. One of the methods is molecular docking, carried out by predicting the free energy of binding as well as its conformation between micromolecule (chemical) and macromolecule (enzyme) [90]. Once the chemical of the oil interacts with an enzyme (by giving a negative value in the binding energy along with its stable conformation), this conformation blocked the enzyme catalytic function in the decomposition process.

The 3D structure of the enzyme is collected from a protein data bank (http://www.rcsb.org), which is a form of cryopurified enzyme crystal [91, 92]. The crystal is then photographed in a three-dimensional form using an X-ray crystallography method. The docking software will be further used to predict the activity of such enzyme including their inhibition by using this $3 \mathrm{D}$ crystal. This technique is very popular in the drug discovery process through enzyme inhibition that blocks pathogenic diseases [93].

In this section, we predicted the capability of some major chemicals in cajuput to interact with cellobiohydrolase from Chaetomium thermophilum (PDB 4a05) [94], native laccase B from Trametes sp. (PDB 3kw7) [95], and lignin peroxidase from Trametes cervina (PDB 3q3u) [96]. The full methodology of this in silico prediction is provided in Supplementary Materials. Table 2 presents the docking result of 10 chemicals identified in cajuput against three enzymes expressed by fungi causing the wood decomposition process. The 10 chemicals have a diverse structure bearing cyclic monoterpene, sesquiterpene alcohol, allylbenzene alcohol, bicyclic sesquiterpene alcohol, acyclic monoterpene alcohol, and acyclic monoterpene which could diverse the binding energy as well as its binding conformation. Figure 5 illustrates the docking conformation of those 10 chemicals into the enzyme's pocket site.

According to the binding energy, all chemicals occupied the pocket site of the three enzymes; however, they would rather interact with cellobiohydrolase than the laccase and peroxidase due to the lower binding energy of cellobiohydrolase compared to laccase and peroxidase. This suggests that the hydrolysis reaction could be the main mechanism of chemicals inhibition to the enzyme, which further led to blocking the wood decomposition process. All chemicals also performed oxidation inhibition toward both oxidase 
TABLE 2: Binding energy of the interaction between chemicals in cajuput leaf oil and the enzymes (laccase, peroxidase, and cellobiohydrolase).

\begin{tabular}{|c|c|c|c|}
\hline \multirow{2}{*}{ Chemicals } & \multicolumn{3}{|c|}{ Binding energy $(\mathrm{kcal} / \mathrm{mol})$} \\
\hline & Laccase & Peroxidase & Cellobiohydrolase \\
\hline 1, 8-Cineole & -5.6 & -5.6 & -6.4 \\
\hline$\alpha$-Eudesmol & -6.3 & -6.4 & -7.8 \\
\hline$\beta$-Eudesmol & -6.5 & -6.4 & -7.8 \\
\hline Eugenol & -5.4 & -6.2 & -6.4 \\
\hline Guaiol & -6.9 & -7.8 & -8.5 \\
\hline Isoeugenol & -5.8 & -6.5 & -6.7 \\
\hline Linalool & -5.5 & -5.6 & -6 \\
\hline Lupene & -4.4 & -9 & -6.1 \\
\hline trans- $\beta$-Ocimene & -5.1 & -5.8 & -6 \\
\hline Viridiflorol & -6 & -7 & -8 \\
\hline
\end{tabular}

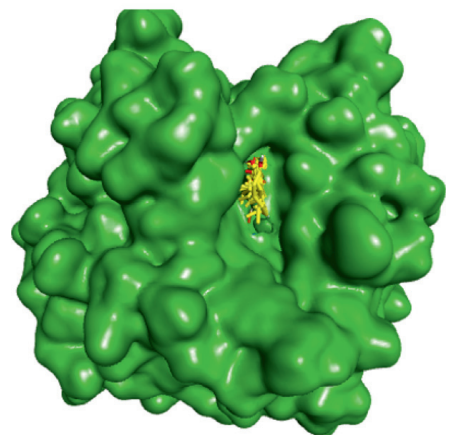

(a)

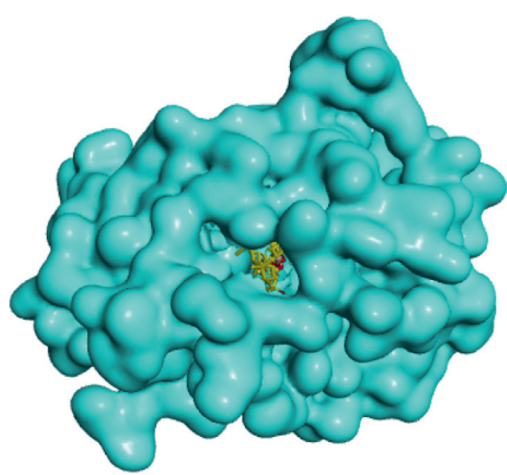

(b)

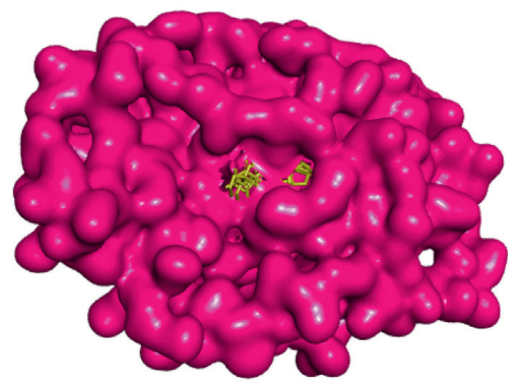

(c)

Figure 5: The overlaid positions of 10 chemicals into the pocket site of (a) cellobiohydrolase, (b) laccase, and (c) peroxidase. The proteins are presented as the surface form, and the ligands are presented as sticks from inside the proteins; yellow color represents carbon, red color represents oxygen, and white color represents hydrogen.

enzymes. Lupene, on the one hand, exhibited the lowest binding energy toward peroxidase among others. However, on the other hand, lupene demonstrated the highest binding energy toward laccase associating with its lowest interaction with the corresponding enzyme. Guaiol, which also is mostly deposited in conifers, showed the strongest affinity to either laccase or cellobiohydrolase. The 1,8-cineole as the major component in cajuput leaves also showed negative values in the binding energy which is comparable to that of guaiol. This finding suggests that lupene, 1, 8 cineole, and guaiol play an important role in inhibiting the wood decomposing process.

The binding mode of guaiol into the pocket site of cellobiohydrolase is represented by hydrogen bond interactions between oxygen $(\mathrm{OH})$-Tyr170 and hydrogen $(\mathrm{OH})$ Asp176 (Figure 6(a)). However, the stable conformation on how guaiol performed the hydrogen bonds was supported by hydrophobic interaction between the sesquiterpene ring with Trp367. The interaction of guaiol with laccase (Figure 6(b)) was also elucidated showing H-bond interaction with Ile63. Nevertheless, the hydrophobic interaction was also performed through its sesquiterpene ring with Ile46, Phe93, Val48, and Phe97. In the interaction between lupene and peroxidase (Figure 6(c)), there was no H-bond interaction observed. However, the lowest binding energy is contributed by hydrophobic interaction with Leu233, Leu239, Val160, Leu172, Leu171, Val183, and Phe46.

\section{Discussion}

Cajuput has been broadly used in healthcare management including pharmaceutical inhalation dosage form, topical liquid for body warming, and aromatherapy, mainly due to its bioactivity and aromatic flavors. The main part of cajuput is the leaves that produce essential oil containing various chemical substances such as 1, 8-cineole (eucalyptol), eugenol, isoeugenol, guaiol, linalool, and viridiflorol. The bioactivity of the chemicals varies due to their unique molecular structure such as chiral carbon, rigidity-flexibility, and stereoselectivity. The bioactivity of plants against microorganisms could be beneficial for many purposes, such as the development of medicine, product recycling process, and other waste management-based industry.

Cajuput leaves produce solid waste which is not efficiently reutilized unless for an organic fuel. Cajuput leaves appear not to be as biodegradable as other leaves. This may due to the residue of the essential oils or other chemicals which has antimicrobial activities against bacteria, fungi, and termites. The antimicrobial activities are potential for the waste product to be used as a wood-preserving agent. 


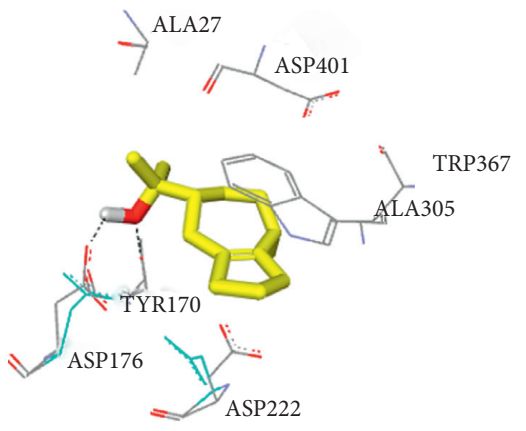

(a)

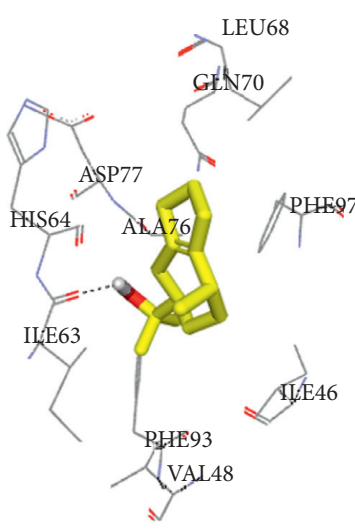

(b)

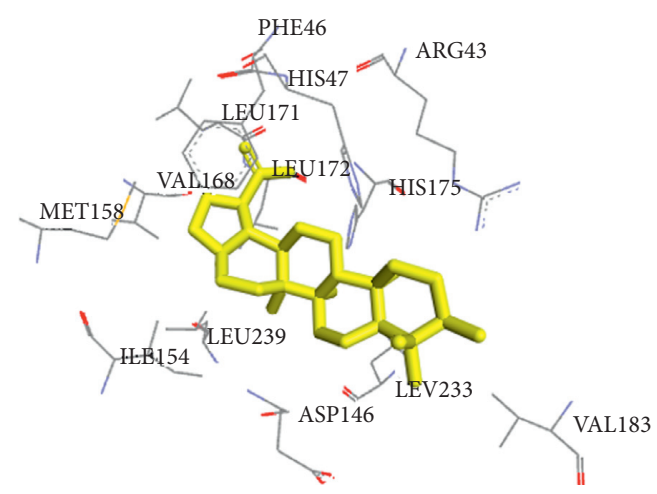

(c)

Figure 6: The binding conformation of (a) guaiol-cellobiohydrolase, (b) guaiol-laccase, and (c) lupene-peroxidase. The proteins are presented as the line form, and the ligands are presented as thick stick forms; yellow color represents carbon, red color represents oxygen, and white color represents hydrogen.

Many experiments investigating the activity of cajuput essential oil as an antimicrobial agent have been performed. Moreover, the detailed molecular mechanism on how the plant fights against decomposition was well studied via in silico and in vitro experiments. Some major chemicals in cajuput essential oil were simulated using a computational molecular docking study, and as expected, several chemicals were performing strong affinities with the enzyme of the microorganism such as fungi. This molecular interaction can simply explain how the functional groups of the chemicals interact with the important amino acid that surrounded the pocket site of protein of interest [97]. Such interactions include hydrogen bond, hydrophobic bond, and even the strongest interaction, i.e., electrostatic interaction may exist. Every single interaction contributes to the free energy of binding. The lower the free energy of binding (larger negative value), the stronger affinity between chemicals and the protein would be. Furthermore, the stronger affinity of chemicals toward protein leads to a higher chance of cajuput to be the protein's inhibitor associates with its anti-biodecomposition effect.

The in silico study could also be applied in other plants having similar properties. Guaiol in conifers has antimicrobial [98] and insecticidal properties [99] due to the alcoholic properties in the structure. The strong interaction between $\mathrm{OH}$ of guaiol and Tyr170 as well as Asp176 of cellobiohydrolase has been well studied using in silico docking as confirmed in the in silico prediction section. Other rational on how the 10 ligands are in silico predicted to inhibit the activity of cellobiohydrolase are incorporated with in vitro results, that on the one hand, 1,8-cineole, $\alpha$-eudesmol, $\beta$-eudesmol, eugenol, and isoeugenol actively inhibit the mycotoxigenic fungus $[100,101]$. On the other hand, linalool has been reported to have antifungal activity against Candida albicans [102].

\section{Conclusions}

The solid waste product of cajuput leaves can be potentially managed as a wood-preserving agent due to the residue of essential oils which have antimicrobial and insecticidal activities. Further processing of the cajuput leaf solid waste may increase the economic value of it. Guaiol, lupene, and 1,8-cineole were predicted to be the chemicals having a responsibility to those biological properties as predicted by an in silico study. In a future study, in vitro experiments should be conducted to examine the corresponding enzyme activity in decomposing fungus against cajuput.

\section{Data Availability}

No data were used to support this study.

\section{Conflicts of Interest}

The authors declare that there are no conflicts of interest regarding the publication of this paper.

\section{Acknowledgments}

The authors thank Sendang Mole, the factory of cajuput essential oil in Playen, Gunung Kidul, Yogyakarta, for donating the cajuput leaves solid waste. This project was financially supported by Sanata Dharma University Internal Research Grant 2020 with a special theme (006/LPPM USD/ I/2020).

\section{Supplementary Materials}

S1: the procedure of molecular docking using AutoDock Vina Program. (Supplementary Materials)

\section{References}

[1] G. K. Efruan, M. Martosupono, and F. S. Rondonuwu, "Bioaktifitas senyawa 1,8 sineol pada minyak atsiri," 2016.

[2] J. J. Malakauseya, S. Sudjito, and M. N. Sasongko, "Pengaruh prosentase campuran briket limbah serbuk kayu gergajian dan limbah daun kayuputih terhadap nilai kalor dan kecepatan pembakaran," Rekayasa Mesin, vol. 4, no. 3, pp. 194-198, 2014. 
[3] S. Mustamu, D. Hermawan, and G. Pari, "Karakteristik biopelet Dari limbah padat kayu putih dan gondorukem," Jurnal Penelitian Hasil Hutan, vol. 36, no. 3, pp. 191-204, 2018.

[4] A. Rahmawati, E. Alberto, and S. Soemarno, "Pengaruh kompos limbah daun minyak kayu putih untuk pertumbuhan semai tanaman kayu putih," Jurnal Tanah Dan Sumberdaya Lahan, vol. 3, no. 1, pp. 293-301, 2017.

[5] J. G. Sutapa and A. N. Hidayat, "Pemanfaatan limbah daun dan ranting penyulingan minyak kayu putih (melaleuca cajuputi, powell) untuk pembuatan arang aktif," 2011.

[6] C. Triwahyuningsih, D. Puspitasari, and I. Gunawan, "Limbah Penyulingan Minyak Kayu Putih Sebagai Energi Alternatif: Kajian Awal," Prosiding Snast, vol. 4, no. 2, 2018.

[7] D. Hendra, "Pembuatan briket daun Dari limbah pengolahan minyak kayu putih," Jurnal Penelitian Hasil Hutan, vol. 10, no. 1, pp. 20-23, 1992.

[8] H. Smith and S. Idrus, "Pengaruh penggunaan perekat sagu dan tapioka terhadap karakteristik briket Dari biomassa limbah penyulingan minyak kayu putih di maluku," Majalah BIAM, vol. 13, no. 2, pp. 21-32, 2017.

[9] S. K. W. Suharto and H. Julendra, "Kajian pemanfaatan limbah penyulingan minyak kayu putih sebagai sumber energi alternatif untuk umkm industri tahu di gunungkidulYogyakarta," in Proceedings of Pemberdayaan Masyarakat Malalui Pemanfaatan Bahan Baku Lokal, Yogyakarta, Indonesia, 2007.

[10] D. R. Pratama, "Pengaruh penggantian rumput lapang dengan limbah penyulingan daun kayu putih (melaleuca cajuputi) pada ransum sapi potong terhadap kecernaan bahan kering dan kecernaan bahan organik (in vitro)," Students E-Journal, vol. 4, no. 3, 2015.

[11] S. Prabaningtyas, "Kandungan hara dan kecepatan dekomposisi limbah penyulingan daun kayu putih (melaleuca leucadendron L.) pada lingkungan yang bervariasi," Jurnal Chimera, vol. 3, no. 2, 2009.

[12] L. C. A. Barbosa, C. J. Silva, R. R. Teixeira et al., "Chemistry and biological activities of essential oils from Melaleuca L. species," Agriculturae Conspectus Scientificus, vol. 78, no. 1, pp. 11-23, 2013.

[13] L. A. Craven and B. J. Lepschi, "Enumeration of the species and infraspecific taxa of Melaleuca (Myrtaceae) occurring in Australia and Tasmania," Australian Systematic Botany, vol. 12, no. 6, pp. 819-928, 1999.

[14] J. J. Brophy, "Potentially commercial melaleucas," Tea Tree, vol. $247,1999$.

[15] R. S. Farag, A. S. Shalaby, G. A. El-Baroty, N. A. Ibrahim, M. A. Ali, and E. M. Hassan, "Chemical and biological evaluation of the essential oils of differentMelaleuca species," Phytotherapy Research, vol. 18, no. 1, pp. 30-35, 2004.

[16] L. A. Craven and I. D. Cowie, "Taxonomic notes on the broad-leaved paperbarks (Myrtaceae, Melaleuca), including the description of one new species from northern Australia and a key to all taxa," Blumea - Biodiversity, Evolution and Biogeography of Plants, vol. 57, no. 3, pp. 207-209, 2013.

[17] G. Shah, A. Chawla, U. S. Baghel, S. Rahar, P. S. Singh, and R. K. Dhawan, "Pharmacognostic standardization of leaves of Melaleuca leucadendron," Pharmacognosy Journal, vol. 5, no. 4, pp. 143-148, 2013.

[18] N. R. Farnsworth, "Biological and phytochemical screening of plants," Journal Of Pharmaceutical Sciences, vol. 5, no. 3, pp. 225-276, 1996.

[19] S. V. Thite, Y. R. Chavan, V. T. Aparadh et al., "Preliminary phytochemical screening of some medicinal plants,"
International Journal of Pharmaceutical, Chemical and Biological Sciences, vol. 3, no. 1, pp. 87-90, 2013.

[20] W. C. Evans, Trease and Evans Pharmacognosy, Saunders Elsevier, Philadelphia, USA, 15th edition, 2009.

[21] A. K. Gupta, "Quality standards of Indian medicinal plants," Indian Council of Medical Research, vol. 1, 2003.

[22] The India Ministry of Health and Family Welfare, The Indian Pharmacopoeia, vol. 2, pp. A53-A54, Controller of Publications, New Delhi, India, 1996.

[23] K. R. Khandelwal, Preliminary Phytochemical Screening, Practical Pharmacognosy, Nirali Prakashan, Pune, India, 10th edition, 2003.

[24] R. W. Doskotch, H.-Y. Cheng, T. M. Odell, and L. Girard, "Nerolidol: an antifeeding sesquiterpene alcohol for gypsy moth larvae fromMelaleuca leucadendron," Journal of Chemical Ecology, vol. 6, no. 4, pp. 845-851, 1980.

[25] J. J. Brophy and E. V. Lassak, "Melaleuca leucadendra L. leaf oil:Two phenylpropanoid chemotypes," Flavour and Fragrance Journal, vol. 3, no. 1, pp. 43-46, 1988.

[26] A. Kumar, S. Tandon, and A. Yadav, "Chemical composition of the essential oil from fresh leaves of Melaleuca leucadendron L. From north India," Journal of Essential Oil Bearing Plants, vol. 8, no. 1, pp. 19-22, 2005.

[27] T. Yoshida, T. Maruyama, A. Nitta et al., "An hydrolysable tannin and accompanying polyphenols from Melaleuca leucadendron," Phytochemistry, vol. 42, no. 4, pp. 1171-1173, 1996.

[28] C.-K. Lee, "A new norlupene from the leaves ofMelaleucaleucadendron," Journal of Natural Products, vol. 61, no. 3, pp. 375-376, 1998.

[29] C.-K. Lee, "Ursane triterpenoids from leaves of Melaleuca leucadendron," Phytochemistry, vol. 49, no. 4, pp. 1119-1122, 1998.

[30] C.-K. Lee, "New triterpenes from the heartwood ofMelaleuca leucadendronL," Journal of the Chinese Chemical Society, vol. 45, no. 2, pp. 303-306, 1998.

[31] C.-K. Lee and M.-H. Chang, "Four new triterpenes from the heartwood ofMelaleuca leucadendron," Journal of Natural Products, vol. 62, no. 7, pp. 1003-1005, 1999.

[32] C.-K. Lee and A. D. "Leucadenone, "Leucadenone A-D, the novel class flavanone from the leaves of Melaleuca leucadendron L," Tetrahedron Letters, vol. 40, no. 40, pp. 7255-7259, 1999.

[33] R. Pujiarti, Y. Ohtani, and H. Ichiura, "Physicochemical properties and chemical compositions of Melaleuca leucadendron leaf oils taken from the plantations in Java, Indonesia," Journal of Wood Science, vol. 57, no. 5, pp. 446-451, 2011.

[34] S. Rattanaburi, W. Mahabusarakam, S. Phongpaichit, and A. R. Carroll, "A new chromone from the leaves of Melaleuca cajuputi Powell," Natural Product Research, vol. 27, no. 3, pp. 221-225, 2013.

[35] M. Muchtaridi, A. Tjiraresmi, and R. Febriyanti, "Analysis of active compounds in blood plasma of mice after inhalation of Cajuput essential oil (Melaleuca Leucadendron L.)," Indonesian Journal of Pharmacy, vol. 26, no. 4, p. 219, 2016.

[36] R. C. Padalia, R. S. Verma, A. Chauhan, and C. S. Chanotiya, "The essential oil composition of Melaleuca leucadendra L. grown in India: a novel source of (E)-nerolidol," Industrial Crops and Products, vol. 69, pp. 224-227, 2015.

[37] R. Fall, S. Ngom, D. Sall, M. Sembène, and A. Samb, "Chemical characterization of essential oil from the leaves of Callistemon viminalis (D. R.) and Melaleuca leucadendron 
(Linn.)," Asian Pacific Journal of Tropical Biomedicine, vol. 7, no. 4, pp. 347-351, 2017.

[38] X. Xie, L. Wu, Z. Cui, M. Yang, and L. Kong, "Melaleucadines $\mathrm{A}$ and $\mathrm{B}$ : two rare benzylic phloroglucinol-terpene hybrids from Melaleuca leucadendron," Tetrahedron Letters, vol. 60, no. 14, pp. 1011-1013, 2019.

[39] S. Luo, Z. Parveen, S. Firdaus-e-Bareen, and S. Mazhar, "Chemical composition, antibacterial and antioxidant activities of essential oils from leaves of three Melaleuca species of Pakistani flora," Arabian Journal of Chemistry, vol. 13, no. 1, pp. 67-74, 2020.

[40] A. Viswan, E. Pushpalatha, S. Arivudainambi et al., "Fractional extraction, isolation and identification of biologically active compounds from Melaleuca leucadendron L. to control the vectors of dengue and filariasis," Journal of Pharmacognosy and Phytochemistry, vol. 9, no. 2, pp. 68-73, 2020.

[41] L. Wu, X. Xie, X. B. Wang et al., "Diverse benzyl phloroglucinol-based meroterpenoids from the fruits of Melaleuca leucadendron," Tetrahedron, vol. 76, no. 28-29, Article ID 131326, 2020.

[42] S. P. P. Falci, M. A. Teixeira, P. F. D. Chagas et al., "Antimicrobial activity of Melaleuca sp. oil against clinical isolates of antibiotics resistant Staphylococcus aureus," Acta Cirurgica Brasileira, vol. 30, no. 7, pp. 491-496, 2015.

[43] R. I. Hakim, W. Wilson, and S. Darmawati, "Uji aktivitas antibakteri ekstrak ethanol daun kayu putih (melaleuca leucadendron L.) terhadap pertumbuhan Methicillin resistant Staphylococcus aureus (MRSA)," In Prosiding Seminar Nasional Mahasiswa Unimus, vol. 2, 2019.

[44] A. Fernández-Calienes Valdés, J. Mendiola Martínez, R. Scull Lizama et al., "In vitro anti-microbial activity of the Cuban medicinal plants Simarouba glauca DC, Melaleuca leucadendron L and Artemisia absinthium L," Memorias do Instituto Oswaldo Cruz, vol. 103, no. 6, pp. 615-618, 2008.

[45] J. Buckle, Clinical Aromatherapy-E-Book: Essential Oils in Practice, Elsevier Health Sciences, London, UK, 2014.

[46] R. Pujiarti, Y. Ohtani, and H. Ichiura, "Chemical compositions, antioxidant and antifungal activities of Melaleuca leucadendron Linn. leaf oils from Indonesia," Wood Research Journal, vol. 3, no. 1, pp. 23-29, 2012.

[47] L. A. Hadwiger and G. N. Agrios, Plant Pathology, Elsevier Academic Press, Amsterdam, Netherlands, 2005.

[48] G. G. Khachatourians and D. K. Arora, Fungal Genomics, Elsevier, Amsterdam, Netherlands, 2004.

[49] S. L. Milind, Citrus Fruit: Biology, Technology and Evaluation, pp. 1-4, Elsevier, Amsterdam, Netherlands, 2008.

[50] P. Rini, Y. Ohtani, and H. Ichiura, "Antioxidant, anti-hyaluronidase and antifungal activities of Melaleuca leucadendron Linn. leaf oils," Journal of Wood Science, vol. 58, no. 5, pp. 429-436, 2012.

[51] C.-Y. Hong, S.-Y. Lee, S.-H. Ryu, and M. Kim, "Wholegenome de novo sequencing of wood rot fungus Fomitopsis palustris (ATCC62978) with both a cellulolytic and ligninolytic enzyme system," Journal of Biotechnology, vol. 251, pp. 156-159, 2017.

[52] E. S. Chapman and C. L. Fergus, "Germination of ascospores of Chaetomium globosum," Mycologia, vol. 67, no. 5, pp. 1048-1052, 1975.

[53] L. J. Standish, C. A. Wenner, E. S. Sweet et al., "Trametes versicolor mushroom immune therapy in breast cancer," Journal of the Society for Integrative Oncology, vol. 6, no. 3, p. 122, 2008.
[54] J. Zhang, H. Wu, D. Jiang, Y. Yang, W. Tang, and K. Xu, "The antifungal activity of essential oil from Melaleuca leucadendra (L.) L. grown in China and its synergistic effects with conventional antibiotics against Candida," Natural Product Research, vol. 33, no. 17, pp. 2545-2548, 2019.

[55] A. A. Nawawi, N. Nakamura, M. Hattori, M. Kurokawa, and K. Shiraki, "Inhibitory effects of Indonesian medicinal plants on the infection of herpes simplex virus type 1," Phytotherapy Research, vol. 13, no. 1, pp. 37-41, 1999.

[56] A. Amer and H. Mehlhorn, "Repellency effect of forty-one essential oils against Aedes, Anopheles, and Culex mosquitoes," Parasitology Research, vol. 99, no. 4, p. 78, 2006.

[57] A. Amer and H. Mehlhorn, "Larvicidal effects of various essential oils against Aedes, Anopheles, and Culex larvae (Diptera, Culicidae)," Parasitology Research, vol. 99, no. 4, pp. 466-472, 2006.

[58] A. Noosidum, A. Prabaripai, T. Chareonviriyaphap, and A. Chandrapatya, "Excito-repellency properties of essential oils from Melaleuca leucadendron L., Litsea cubeba (Lour.) Persoon, and Litsea salicifolia (Nees) on Aedes aegypti (L.) mosquitoes," Journal of Vector Ecology, vol. 33, no. 2, pp. 305-312, 2008.

[59] E. Pushpalatha and K. A. Viswan, "Adulticidal and repellent activities of Melaleuca leucadendron (L.) and Callistemon citrinus (Curtis) against filarial and dengue vectors," Entomon, vol. 38, no. 3, pp. 149-154, 2013.

[60] A. Noosidum, T. Chareonviriyaphap, and A. Chandrapatya, "Synergistic repellent and irritant effect of combined essential oils onAedes aegypti (L.) mosquitoes," Journal of Vector Ecology, vol. 39, no. 2, pp. 298-305, 2014.

[61] K. A. Viswan, V. K. Rahana, and E. Pushpalatha, "Repellent and adulticidal efficacy of essential oils of two indigenous plants from Myrtaceae family against Lasioderma serricorne F," Journal of Biopesticides, vol. 7, p. 70, 2014.

[62] E. L. V. I. S. Adjalian, P. H. I. L. I. P. P. E. Sessou, B. O. N. I. F. A. C. E. Yehouenou et al., "Anti-oviposition and repellent activity of essential oil from Melaleuca leucadendron leaf acclimated in Bénin against the Angoumois grain moth," International Journal of Biology, Pharmacy and Allied Sciences, vol. 4, no. 2, pp. 797-806, 2015.

[63] C. A. G. da Câmara, J. P. R. de Melo, and M. M. C. da Silva, "Insecticidal activity of Melaleuca leucadendron and Citrus reticulata essential oils against larvae of Plutella xylostella," Revista de Protección Vegetal, vol. 30, 2015.

[64] M. I. Rashid, L. H. Mujawar, T. Shahzad, T. Almeelbi, I. M. I. Ismail, and M. Oves, "Bacteria and fungi can contribute to nutrients bioavailability and aggregate formation in degraded soils," Microbiological Research, vol. 183, pp. 26-41, 2016.

[65] L. Burhenne, J. Messmer, T. Aicher, and M.-P. Laborie, "The effect of the biomass components lignin, cellulose and hemicellulose on TGA and fixed bed pyrolysis," Journal of Analytical and Applied Pyrolysis, vol. 101, pp. 177-184, 2013.

[66] R. Guevara, L. Villedo, and A. Nájera, "Soil meso-fauna patterns and experiments on leaf litter mite fungivory: preferences, effects on fungal reproduction and decomposition," Acta Zoológica Mexicana, vol. 87, pp. 1-15, 2002.

[67] D. Djarwanto, S. Suprapti, and R. A. Pasaribu, "Dekomposisi daun dan ranting mangium dan ekaliptus oleh delapan isolat fungi pelapuk," Jurnal Penelitian Hasil Hutan, vol. 27, no. 4, pp. 303-313, 2009.

[68] N. A. A. Mohamad, The Effect of Coptotermes Kalshoveni Kemner towards Melaleuca Cajuputi (Cajuput) Wood and 
Acacia Mangium Wood, Universiti Malaysia Kelantan, Kota Bharu, Malaysia, 2016.

[69] Z. Zulyusri, D. Desyanti, and U. Mardia, "Keefektifan daun sangitan (Sambucus javanica reinw) sebagai insektisida nabati dalam pengendalian rayap tanah (Coptotermes sp.)," Prosiding Semirata, vol. 1, no. 1, 2013.

[70] A. Noviansari, S. Sudarmin, and K. Siadi, "Transformasi metil eugenol menjadi 3-(3, 4- dimetoksi fenil)-1-propanol dan uji aktivitasnya sebagai antibakteri," Indonesian Journal of Chemical Science, vol. 2, no. 2, 2013.

[71] A. N. Kutana, M. Muin, and A. Arif, "Produksi umpan rayap Dari limbah bahan organik dan efektivitasnya dalam pengendalian serangan Coptotermes sp," Perrennial, vol. 14, no. 2, pp. 66-70, 2018.

[72] N. F. Haneda and A. Firmansyah, "Keanekaragaman Rayap Tanah di Hutan Pendidikan Gunung Walat Sukabumi," Jurnal Silvilkultur Tropis, vol. 3, no. 2, p. 92â, 2012.

[73] P. D. P. Nugroho, "Kisah mbah rustam, dirayu perhutani buka rahasia bibit kayu putih anti-rayap (2)," 2019.

[74] A. Ismanto and A. Baedowi, "Efikasi ekstrak AkarTuba dalam mengendalikan rayap tanah Macrotermes gilvus hagen pada pertanaman kayu putih," Jurnal Ecogreen, vol. 5, no. 1, pp. 57-62, 2019.

[75] M. Muslich and S. Rulliaty, "Kelas awet 15 jenis kayu andalan setempat terhadap rayap kayu kering, rayap tanah dan penggerek di laut," Jurnal Penelitian Hasil Hutan, vol. 29, no. 1, pp. 67-77, 2011.

[76] Y. Indrayani, M. Muin, and T. Yoshimura, "Crude extracts of two different leaf plant species and their responses against subterranean termite Coptotermes formosanus," Nusantara Bioscience, vol. 8, no. 2, pp. 226-231, 2016.

[77] Y. Fukasawa, T. Osono, and H. Takeda, "Wood decomposing abilities of diverse lignicolous fungi on nondecayed and decayed beech wood," Mycologia, vol. 103, no. 3, pp. 474-482, 2011.

[78] K. E. L. Eriksson, R. A. Blanchette, and P. Ander, Microbial and Enzymatic Degradation of Wood and Wood Components, Springer Science \& Business Media, Berlin, Germany, 2012.

[79] S. Suprapti and D. Djarwanto, "Ketahanan Lima jenis kayu asal ciamis terhadap sebelas strain jamur pelapuk," Jurnal Penelitian Hasil Hutan, vol. 32, no. 3, pp. 189-198, 2014.

[80] K. Sri, N. TjuTju, and G. Gusmailina, "Biodegradasi komponen kimia pada limbah lignoselu- losa oleh jamur perusak kayu (biodegradation of wood chemical components in lignocellulosic wastes by whiterot fungi)," Jurnal Penelitian Hasil Hutan, vol. 11, no. 2, pp. 57-64, 1993.

[81] A. M. Romaní, C. Mille-Lindblom, L. J. Tranvik et al., "Interactions of bacteria and fungi on decomposing litter: differential extracellular enzyme activities," Ecology, vol. 87, no. 10, pp. 2559-2569, 2006.

[82] J. Adrio and A. Demain, "Microbial enzymes: tools for biotechnological processes," Biomolecules, vol. 4, no. 1, pp. 117-139, 2014.

[83] T. K. Kirk and R. L. Farrell, "Enzymatic "combustion:" the microbial degradation of lignin," Annual Review of Microbiology, vol. 41, no. 1, pp. 465-501, 1987.

[84] R. H. Marchessault and P. R. Sundararajan, "Cellulose," in The Polysaccharides, pp. 11-95, Academic Press, Cambridge, MA, USA, 1983.

[85] R. G. Thorn, C. A. Reddy, D. Harris, and E. A. Paul, "Isolation of saprophytic basidiomycetes from soil," Applied and Environmental Microbiology, vol. 62, no. 11, pp. 4288-4292, 1996.
[86] P. Longoni, M. Rodolfi, L. Pantaleoni et al., "Functional analysis of the degradation of cellulosic substrates by a Chaetomium globosum endophytic isolate," Applied and Environmental Microbiology, vol. 78, no. 10, pp. 3693-3705, 2012.

[87] L. J. Jönsson, E. Palmqvist, N.-O. Nilvebrant, and B. HahnHägerdal, "Detoxification of wood hydrolysates with laccase and peroxidase from the white-rot fungus Trametes versicolor," Applied Microbiology and Biotechnology, vol. 49, no. 6, pp. 691-697, 1998.

[88] B. K. Yap, C.-Y. Lee, S. B. Choi, E. E. Kamarulzaman, M. Hariono, and H. A. Wahab, "In silico identification of novel inhibitors," Encyclopedia of Bioinformatics and Computational Biology, vol. 3, pp. 761-779, 2019.

[89] M. Hariono, S. H. Yuliani, E. P. Istyastono, F. D. O. Riswanto, and C. F. Adhipandito, "Matrix metalloproteinase 9 (MMP9) in wound healing of diabetic foot ulcer: molecular target and structure-based drug design," Wound Medicine, vol. 22, pp. 1-13, 2018.

[90] M. Hariono, R. F. Nuwarda, M. Yusuf et al., "Arylamide as potential selective inhibitor for matrix metalloproteinase 9 (MMP9): design, synthesis, biological evaluation, and molecular modeling," Journal of Chemical Information and Modeling, vol. 60, no. 1, pp. 349-359, 2019.

[91] M. Hariono, H. A. Wahab, M. L. Tan et al., "9-Benzyl-6benzylsulfanyl-9H-purin-2-amine," Acta Crystallographica Section E: Structure Reports Online, vol. 70, no. 3, p. 288, 2014.

[92] M. Hariono, N. Ngah, H. A. Wahab et al., "2-Bromo-4-(3, 4dimethyl-5-phenyl-1, 3-oxazolidin-2-yl)-6-methoxyphenol," Acta Crystallographica Section E: Structure Reports Online, vol. 68, no. 1, pp. 35-36, 2012.

[93] C. F. Adhipandito, D. P. K. S. Ludji, E. Aprilianto et al., "Matrix metalloproteinase9 as the protein target in antibreast cancer drug discovery: an approach by targeting hemopexin domain," Future Journal of Pharmaceutical Sciences, vol. 5, no. 1, p. 1, 2019.

[94] A. J. Thompson, T. Heu, T. Shaghasi et al., "Structure of the catalytic core module of theChaetomium thermophilumfamily GH6 cellobiohydrolase Cel6A," Acta Crystallographica Section D Biological Crystallography, vol. 68, no. 8, pp. 875-882, 2012.

[95] H. Ge, Y. Gao, Y. Hong et al., "Structure of native laccase B fromTrametessp. AH28-2," Acta Crystallographica Section F Structural Biology and Crystallization Communications, vol. 66, no. 3, pp. 254-258, 2010.

[96] Y. Miki, F. R. Calviño, R. Pogni et al., "Crystallographic, kinetic, and spectroscopic study of the first ligninolytic peroxidase presenting a catalytic tyrosine," Journal of Biological Chemistry, vol. 286, no. 17, pp. 15525-15534, 2011.

[97] E. P. Istyastono, N. Yuniarti, M. Hariono et al., "Binary quantitative structure-activity relationship analysis in retrospective structure based virtual screening campaigns targeting estrogen receptor alpha," Asian Journal of Pharmaceutical and Clinical Research, vol. 12, no. 1, pp. 206-211, 2017.

[98] M. I. Choudhary, I. Batool, M. Atif, S. Hussain, and fnm Atta-ur-Rahman, "Microbial transformation of (-)-Guaiol and antibacterial activity of its transformed products," Journal of Natural Products, vol. 70, no. 5, pp. 849-852, 2007.

[99] T. Liu, C. J. Wang, H. Q. Xie et al., "Guaiol-a naturally occurring insecticidal sesquiterpene," Natural Product Communications, vol. 8, no. 10, 2013. 
[100] C. Morcia, M. Malnati, and V. Terzi, "In vitro antifungal activity of terpinen-4-ol, eugenol, carvone, 1, 8-cineole (eucalyptol) and thymol against mycotoxigenic plant pathogens," Food Additives \& Contaminants: Part A, vol. 29, no. 3, pp. 415-422, 2012.

[101] C. L. Ho, K. P. Hsu, Y. H. Tseng et al., "Composition and antifungal activities of the leaf essential oil of Litsea coreana from Taiwan," Natural Product Communications, vol. 5, no. 10, pp. 1677-1680, 2010.

[102] I. J. Dias, E. R. I. S. Trajano, R. D. Castro et al., "Antifungal activity of linalool in cases of Candida spp. isolated from individuals with oral candidiasis," Brazilian Journal of Biology, vol. 78, no. 2, pp. 368-374, 2018. 